\title{
Reproductive nanotechnology: tretinoin-loaded lipid-core nanocapsulesand in vitro embryos production
}

\author{
Caroline Lucas ${ }^{1 *}$, Mariana Remião ${ }^{1}$, Eliza Rossi ${ }^{1}$, Priscila De Leon ${ }^{1}$, Aline Ourique ${ }^{2}$, William Domingues ${ }^{1}$, \\ Cristina Haas ${ }^{1}$, Vinicius Campos ${ }^{1}$, Ruy Beck², Fabiana Seixas ${ }^{1}$, Tiago Collares ${ }^{1}$ \\ From 5th Congress of the Brazilian Biotechnology Society (SBBIOTEC) \\ Florianópolis, Brazil. 10-14 November 2013
}

\section{Background}

The improvement of in vitro maturation (IVM) protocols through the supplementation with different molecules has become an alternative to increase the culture medium efficiency. Tretinoin (TTN, all-trans retinoic acid, ATRA), is an active metabolite of vitamin A [1], that mediates cell proliferation, cell differentiation, and embryonic development process. In in vitro production embryos systems, TTN acts improving cytoplasmic maturation process in oocytes, developmental competence in early embryos, and quality in blastocysts [2]. Studies have been demonstrated the presence of $\alpha, \beta$ and $\gamma$ subtypes of retinoic acid receptors (RAR $\alpha$, RAR $\beta$, $\operatorname{RAR}_{\gamma}$ ) for TTN in oocyte, hatched blastocysts, and cumulus cells [3]. This molecule can also be used for treatment of skin disorders and for anti-tumor treatment, so researchers have been associated TTN with polymeric nanoparticles to protect it from degradation and to improve its chemical stability and efficacy [4]. The aim of present study was to test the concentrationdependent effect of supplementation of free tretinoin (TTN) and tretinoin-loaded lipid-core nanocapsules (TTN-LNC) in bovine in vitro maturation media, and its influence in reactive oxygen species (ROS) production in two-to four-cell stage embryos. In conclusion, tretinoin- loaded lipid-core nanocapsules added in in vitro maturation media highly protects embryos at early stage of development against oxidative stress.

\section{Methods}

The experimental groups were established, and cumulus-oocyte complexes (COCs) were matured in oocyte in vitro maturation medium supplemented with $0.25,0.5$ and $1 \mu \mathrm{M}$ of TTN-LNC or TTN. Control groups of COCs matured without treatment and treated only with blank lipid-core-nanocapsules (LNC) were also examined. The oocytes were in vitro fertilized in order to evaluate the ROS levels in embryos produced by the different treatments. The ROS formation was evaluated in two-to four-cell stage embryos as previously described [5] with some modifications.

\section{Results and conclusions}

ROS production was lower in embryos derived from oocytes matured in the presence of TTN or TTN-LNC. Both treatments TTN and TTN-LCNC protect the cell more effectively against oxidative damage reducing the ROS production. A significant reduction $(\mathrm{p}<0.05)$ in ROS production was detected in the presence of TTNLCNC compared with controls. There was no difference between the concentrations in TTN and TTN-LNC groups. Tretinoin-loaded lipid-core nanocapsules offers an increased protection against oxidative stress in embryos produced in vitro. The studies at the molecular level using oocyte competence markers are alternatives to clarify the function of lipid-core nanocapsules in in vitro maturation and in embryonic development.

\section{Acknowledgements \\ CAPES, CNPq and FAPERGS.}

\section{Authors' details}

${ }^{1}$ Universidade Federal de Pelotas, Pelotas, RS, Brazil. ${ }^{2}$ Universidade Federal do Rio Grande do Sul, Porto Alegro, AM, Brazil. 


\section{References}

1. Ourique AF, Azoubel S, Ferreira CV, Silva CB, Marchiori MC, Pohlmann AR, Guterres SS, Beck RC: Lipid-core nanocapsules as a nanomedicine for parenteral administration of tretinoin: development and in vitro antitumor activity on human myeloid leukaemia cells. Journal of Biomedical Nanotechnology 2010, 79:214-223.

2. Deb GK, Dey SR, Bang Jl, Cho SJ, Park HC, Lee JG, Kong IK: 9-cis retinoic acid improves developmental competence and embryo quality during in vitro maturation of bovine oocytes through the inhibition of oocyte tumor necrosis factor-alpha gene expression. Journal of Animal Science 2011, 89(9):2759-276.

3. Mohan M, Malayer JR, Geisert RD, Morgan GL: Expression patterns of retinoid $\times$ receptors, retinaldehyde dehydrogenase, and peroxisome proliferator activated receptor gamma in bovine preattachment embryos. Biology of Reproduction 2002, 66(3):692-700.

4. Fontana MC, Coradini K, Guterres SS, Pohlmann AR, Beck RCR:

Nanoencapsulation as a Way to Control the Release and to Increase the Photostability of Clobetasol Propionate: Influence of the Nanostructured System. Journal of Biomedical Nanotechnology 2009, 5(3):254-263.

5. Morado SA, Cetica PD, Beconi MT, Dalvit GC: Reactive oxygen species in bovine oocyte maturation in vitro. Reproduction, Fertility and Development 2009, 21(4):606-614.

doi:10.1186/1753-6561-8-S4-P168

Cite this article as: Lucas et al:: Reproductive nanotechnology: tretinoinloaded lipid-core nanocapsulesand in vitro embryos production. BMC Proceedings 2014 8(Suppl 4):P168.

\section{Submit your next manuscript to BioMed Central and take full advantage of:}

- Convenient online submission

- Thorough peer review

- No space constraints or color figure charges

- Immediate publication on acceptance

- Inclusion in PubMed, CAS, Scopus and Google Scholar

- Research which is freely available for redistribution

Submit your manuscript at www.biomedcentral.com/submit 